To save repetition I will here venture upon a digression and say something about water-drinking in relation to dropsy in general. Crescit indulgens sibi dirus hydrops expresses the belief of antiquity, and that this has come down to modern times is known to the readers of Buswell. ${ }^{2}$ Dr. Johnson described the wine in Scotland before the union as "weak stuff, the refuse of France, which would not make you drunk." Whereapon, says Boswell, standing up for the honour of his country. "I assure you, Bir, there was a great deal of drunkenness." "No, Sir," retorts Johnson, "there were poople who died of dropsies which they contracted in trying to get drank." The immortal Pecksniff ${ }^{3}$ is at one with the great Lexicographer in attributing dropsy to aqueous drinks. "If we indulge in harmless flaids we get the dropsy; if in exciting liquids we get drank. What a soothing reflection is that!" The fact is that water does not cause dropsy, but alcohol does, which should be "a soothing reflection" to those worthies the teetotalers. $A$ priori, it might have been expected that much water wou'd cause dropsy by increasing intravascular pressure and diluting the blood; but practically so long as the natural exits are free the excess of water will make its way out by them and not by transudation into the tissues. Water is diuretic, diaphoretic, and purgative, and will not accumulate so long as it can escape. Water may eren be a cure for dropsy instead of a cause of it. In acute renal dropsy dependent on tubal nephritis water may be the best diuretic we can employ. It increases the urine, washes out the tubes, carries off the accumulated excreta and relieves the dropsy, together with the other symptoms. have given a pint of distilled water every four hours with the beneficial results I hava mentioned. Bat if the kidneys are so far gone that they cannot respond the dropsy will be increased instead of diminished; this I have also seen. The contrary plan, the cutting off of water, is one which should never be employed in the presence of renal disease; the dropsy may possibly be lessened, but the tendency to uræmia will be increased. In some forms of chronic renal disease the urine is thin, poor, and copious, and the patient habitaally thirsty. Bo long as he is allowed to drink according to his needs the arine may remain superabundant and make up in quantity what it wants in quality. If on any false theory the drink is restricted what we may expect is uræmia. I will bring this digression to an end with the conclusion that there is a little truth and much error in the old dictum. Water increases dropsy when the kidneys are incapacitated, not otherwise. It is actually a remedy for dropsy when this is caused by nephritis, mainly tubal, and not too obstinate. The great sonrce, at least of abdominal dropsy, is not water, bat alcohol.

\section{ON FUNCTIONAL HEART MURMURS : THE MIMICRY OF ORGANIC DISEASE. ${ }^{1}$}

BY DAVID DRUMMOND, M.D., D.C.L.

HEYSIOLAX TO THE ROYAL INFIRMARY, NEWCASTLE-ON-TYNE; LECTORER ON PATHOLOGY, DURHAM UNIVERSTTY.

DOUBTLESs all will agree that an occasional survey of the clinical signs and their interpretation, which form the groundwork of our professional opinions, is of service, and that even commonplace subjects, if they happen to be of practical clinical interest, are deserving of our renewed attention. I have not, I fear, much that is new to say about heart murmurs in what I may call their pseado-form; bat if an excuse is necessary for the subject of this paper it will be sufficiently supplied if $I$ succeed in showing that we are not standing still, and that the last word has not yet been said on fanctional heart murmars. It is often urged that the stady of the physical characters of murmurs is unprofitable, as everyone knows the significance of a morbid sound occupying a given position in the cardiac cycle; and it is further arged that the marmur, in conveying to the mind of a practitioner the impression that the patient is suffering from mitral or aortic disease, as the case may be, conveys precisely the same information to all, and in doing so has, so to speak, served its diagnostic parpose, and there

2 Boswell's Tour to the Hebrides, p. 251.

3 Charles Dickens: Martin Chuzalewit, 11

1 A paper read before the Northumberland and Durham Medical Society. is an end of it. Obviously this view is unscientific, because narrow, and tends to shut the door against further research ; indeed, it forecloses discussion, and places the seal of finality on points which are still open to opinion. That murmurs are not always evidence of valvular disease and are seldom the measure of its extent are traths that are not sufficiently borne in mind in clinical diagnosis. And beyond question our stethoscopes often tell as too much or too little--too much if they constrain as to condemn a patient who has little if anything, wrong with him ; and too little if they suggest the bare fact alone of a certain valvular defect without an inkling of the nature or extent of the damage. The question that naturally occurs to us on discovering a murmur is : What does it signify ? Is it organic? There are of course murmurs that bear the undeniable stamp of organic disease, as, for example, those belonging to aortic regurgitation and mitral stenosis; but the systolic murmurs of the mitral, tricuspid, and aortic areas have all a pseudo-form which resembles their prototype at times very closely. It is the characteristics of these fanctional murmurs that I wish to discass. Belonging to this group there are at least three varieties which I may categorise as follows: (a) the cardio.hæmic or anæmic ; (b) the neuro-typtic ${ }^{2}$ or cardio-muscular; and (c) the cardiorespiratory. With the first all are familiar, and it requires but very brief reference. The murmur is, perhaps, best marked in typical examples of chlorosis, but it is by no means confined to the anæmic, and is often present in rosy and fairly-robust people. There are few delicate women, particularly if their chest walls are thin, who are without a trace of this murmur ; and it is quite common to meet it in children who are below par from any cause, especially when they are examined in the recumbent posture. The hæmic murmur is usually a soft-blowing sound, and is, of course, systolic in time. It is best heard in the second interspace close to the left side of the sternum, but is often conducted into the lower reaches of the tricuspid area and downwards and outwards to the apex. In the mitral area it seldom outruns the limits of the heart walls, and is, consequently, so far as the apex is concerned, more limited than the somewhat analogous bruit of organic mitral regurgitation. The hæm:c murmur is not always soft in character; it may be exceedingly rough, and is at times scratching. The roughness is often an added quality, and may be caused by unusual cardiac excitement. Particularly is the murmur liable to be rough when in addition to anæmia there is febrile excitement, as in rheumatic illness, a fact that adds to the importance of the diagnostic question. In common with other murmurs of this (functional) group, the hæmic is mach influenced by the posture of the body. It is loudest when the patient is in the horizontal position, and at a minimum when the erect posture is assumed; but in some cases the difference under these conditions of posture is not great. It matters little, as a rule, whether the decubitus is dorsal or lateral. To the statement of Handford that the murmur is absent when the patient is lying on the face I am unable to subscribe. On the contrary, in several instances I have found that the bruit was loudest when the patient was placed in the prone position. It is commonly influenced by the respiratory acts, being generally loudest at the end of expiration and commencement of inspiration, and is often inaudible when the patient holds her breath at the end of forced inspiration. The physical causes of the cardio-bæmic murmur are no doubt still in dispate, but as $I$ do not intend at present to discuss this point I shall content myself with the remark that I believe it to be the result of vibrations generated in the conus arteriosus of the right ventricle, at least in the cases in which its maximum occupies the second and third interspaces close to the sternum on the left side. The question arises: For the murmur of what organic lesions may the hæmic bruit be mistaken? To which the reply is readily forthcoming. It may be supposed to indicate roughness or thickening at the aortic orifice, or perhaps mitral or tricuspid regurgitation. But, to be practical, it is most frequently mistaken for organic aortic and mitral systolic murmurs. I have been much impressed with the frequency with which organic aortic systolic bruits begin in the third left interspace close to the sternum, where they may be clearly audible for a considerable time before they spread into the right second

2 I have ventured to suggest this name from neuron and tupto as convenient and fairly expressive.

3 It is only reasonable to suppose that under certain conditions mitral incompetency takes place in anæmia, when the murmur will be andible in the mitral area. 
interspace, or even before they are distinct in the mid-sternal region. For example, one of the first indications of gouty beart mischief in the contracting form of kidney disease may be a rough, often scratching brait, best heard in the interspace belo $\pi$ the third rib, close to the sternam. This marmur is at first audible over a very limited area, though not infrequently it extends down to the interspace below (fourth). I have known this marmur precede the appearance of albumen in the urine by two months, and on several occasions it has given the clue to the diagnosis of chronic Bright's disease, a diagnosis that is still further suggested by the accompanying rapid and high tension pulse. I repeat that hre mic murmurs may be erroneously taken to indicate organic mitral regurgitation, and endocarditis and atheroma at the aortic orifice the results of rheumatic, gouty, and possibly malignant endocarditis. The diagnosis is often difficult, and in few cases can be decided apon physical signs alone, yet attention to the character and behaviour of the murmur under test of careful examination may be of signal service. The true organic mitral systolic bruit usually extends beyond the apex; the hrmic rarely does, unless the anæmia is very pronounced. The organic bruit is not much influenced by posture; the brmic varies markedly; the organic is only slightly modified by the respiratory acts. It is usually loudest at the end of expiration, and diminishes as the expanding chest wall separates the stethoscope from the heart in deep inspirations; but in no case, as far as I am aware, does a long breath (evon when held) entirely conceal an organic bruit, whereas it is quite common for hæmic murmurs to disappear ander these circumstances.

The fact that the bromic murmur may be rough in quality is not, $I$ am inclined to think, generally known; indeed, it is so usually credited with the properties of softness, and of undergoing abatement wnder the stimnlus of exertion, that upon these points it stands or falls. It is obvious that we must hesitate before we condemn a patient, should he be the possessor of a murmur, as the subject of organic heart mischief because of the quality of roughness, and because it does not decline on exertion, for in truth the hæmic bruit often becomes louder and harsher on exertion. This change in the character of the nurmur may usually be ascribed to the supervention of the shock-brait-the neuro-typtic murmur presently to be described-as the result of excited muscular action. In addition to a modified bæmic bruit there may then be audible a rough buzzing sound, which is best heard at the commencement of the systole, and is loudest in the third interspace. The union of these psendo-murmurs is commor, and may closely simulate organic disease. Even the act of sitting up will at times induce this combined bruit, for the heart of an angmic patient is easily excited. It is often audible in the left interscapular region, but it generally lingars here only so long as there is excitement, and digappears as the heart returns to its normal rhythm. This alliance of murmurs way be very puzzling, and many a young heart is condernned-I had almost said "unheard" when the disturbance is purely functional. The difficulty is particularly great hen, for example, we have to do with a nervous young person whose history is not entirely free from a suspicion of rheumatism. The fact that perfect rest-say, for ten or fifteen minutes, when the heart is reduced some twenty or more beats-modifies the bruit considerably, robbing it of its roughness and leaving the apex free, is very suggestive of functional disturbance. Hearts belonging to this group (combined hæmic and neuro-typtic) as well as to the next (neuro-typtic) possess a highly nervous mechanism, and are subject to a form of palpitation or over-action of which the patient may be entirely ignorant. To this excited action the morbid sound may be ascribed. The neuro-typtic bruit is of the greatest importancs and is very often responsible for grave mistakes in diagnosis. I have known the life of an able and basy surgeon embittered in the belief that he was suffering from advancing mitral disease - he heard the murmur himself with the donble stethoscove, and his neighbour confirmed the diagnosis; and in another instance I was called to see a medical man who had bəen confined to bed for a month with a supposed attack of endocarditis.

But it is chiefly in connexion with life assurance that mistakes arise. It has frequently been my lot to encourage and reassure by a hopefal opinion nervous young men who were rejected for life assurance on the medical report upon the condition of their hearts. I need scarcely add parenthetically that in attampting to establish under these circams sances the patient's confidence in himself, I have always been carefal to avoid doing so at the expense of the reputation of the medical referee by recognising the existence of the heart mischief while expressing the hope that it would prove to be functional and temporary. Other cases have come under my notice apart from the question of life assurance, and, with rare exceptions, the patients have sought advice on account of their hearts. I have said that the patient is usually ignorant of the cardiac excitement or palpitation that accompanies the functional murmur I am about to describe; but this is only partly correct, for, though nnaware of the existence of chronic palpitation, he is conscious of a feeling of discomfort of which the palpitation is probably the cause. The following case is fairly typical.

CASE 1.-A man aged fifty, holding a position the daties of which were chiefly clerical, consulted me for pains \&c. in the chest and legs. He was a very nervous man, and after beating abont the bush for some time stated that he had been the subject of heart disease for upwards of eleven years. It was with some degree of reluctance that he allowed me to examine his chest, as he had never submitted to examination before, owing to a morbid dread of having his fears confirmed. I anticipated an easy task, fully expecting to be able to dismiss from his mind all solicitude for the future; for, as a rule, a nervous patient who diagnoses his own case has absolutely nothing the matter with his heart. I found, however, that I was mistaken; for on auscultation I discovered a loud systolio murmur audible at the apex, but loudest at the union of the fourth rib with the sternum. The pulse-rate was 100 to the minute, and the apex beat was a somewhat violent shock. It was difficult to localise, but it was not displaced. The murmur was of a buzzing or whizzing character, and was only conducted a short distance beyond the apex. It was very distinctly audible with the single stethoscope, though loudest when the double was employed. After resting on his back for upwards of twenty minutes, when the palserate was reduced to 86 , it was observed that the shocking action and the murmur had absolutely disappeared. They both returned, however, on allowing him to stand up and talk about his symptoms. I formed the opinion that the bruit was the result of sonorous vibrations conducted to the stethoscope on account of the peculiar ventricular shock, which produced a somewhat sibilant buzzing murmur, and that there was no mitral incompetency.

A number of cases have come under my notice which resemble the above more or less closely, but I shall only refer to a few as illustrating different phases, particularly with reference to the maximum point of the murmur.

CASE 2.-A man aged thirty-five, the subject of facial palsy, stated that his medical man had discovered his heart was "wrong" about four years previously. He was an extremely nervous man, and complained, among other symptoms, of almost constant palpitation. Under examination the heart was excited and jerky (120 in the minute), and there was an apparent increase in the area over which the impulse could be felt and seen. A well-marked systolic murmur was andible at the apex and was conducted about two inches to the left. Its maximum was just above the apex beat. The murmur was rough and was rendered less distinct by pressing the stethoscope firmly on the chest. It entirely disappeared even during excitement, when be held his breath after a deep inspiration, and when he lay on the right side; nor was it any longer andible when the heart settled down after a prolonged rest.

CASE 3.-A young man aged twenty-two was sent to me by his medical attendant for an affection of the heart. He complained of dyspepsia, shortmess of breath on exertion, and a sensation amounting at times to pain in the præcordium. The heart was rapid (about 100) and the impulse was distinctly heaving. There was no displacement of the apez. A lond systolic murmur was audible along the left border of the sternum from the second to the fifth interspaces. It was rough and vibrating at its commencement, and soft and blowing towards its termination. It was londest in the fourth interspace and was feebly audible at the apex, in which area it becarne less distinct on placing him on his left side, whilst as the result of rest it receded altogather from the apex and remained limited to the left border of the sternum. On the two or three occasions on which I ezamined this case the murmur, though reduced in intensity and extent of area over which it was audible by rest, did not quite disappear. It is only fair to say that in spite of the repose the heart remained rapid and excited ; in other words, that it did not respond satisfactorily to rest. 
It is common to find cases of this kind among children, but here the neuro-typtic bruit is asually associated with the true hæmic murmur - a fact that should be borne in mind when applying the repose test, for as the heart settles down the anæmic part of the brait may become louder as the shockproduced sound diminishes. The fact, however, as I have already remarked, that the apex is left free from murmur as the resalt of rest is of great diagnostic value. In children it is, unfortunately, very difficult to manipulate the patient so as to abolish all agitation from the impulse, for the peculiar vibrating shock that would seem to underlie the murmur is apparently very easily aroused. I have often longed to examine the case during sleep, and I suspect some cases could only be cleared up in this way. It is also worthy of note that this murmur is not rendered more marked, but is rather lessened, by placing the patient on the left side, a manceurre that nearly always intensifies organic bruits belonging to the mitral area. As a rale, in cases in which the neuro-typtic murmur is well marked, the morbid sound is andible whenever the patient is examined, under even slight degrees of excitement, in the erect posture, but in the following case the murmur disappeared entirely after a few weeks' rest and treatment. (Bromide of potassiam and arsenic, with rest, were prescribed.)

CASE 4.--An athletic young man aged twenty complained of discomfort about his heart, with palpitation and shortness of breath on exertion. He was highly nervous. The apex beat was somewhat diffused, and was a little displaced to the left. It communicated a distinct shock to the hand, and the heart was rapid (90). A low-pitched, burring, systolic murmur was audible at the apex, . but was not conducted towards the left, though it could be traced towards the right as far as the sternum in the fourth and fifth interspaces. After a few minutes' rest on the back it entirely vanished, but not until the cardiac excitement subsided. When examined a month later the murmur was no longer andible.

I pass now to a form of pseado-murmurs that has long puzzled clinical observers, I refer to the so-called cardiorespiratory murmur. This adventitions sound is very common in nervous people daring inspiration, but is frequently audible during the whole of the respiratory cycle. It is short and whiffing, and corresponds in point of time, as a rule, with the first sound. It can scarcely be said to favour any particular area of the precordium, though it is perhaps most, frequently andible in the neighbourhood of the apex, either to the right or to the left of the heart, or it may be below it, thongh it is often in the true mitral area itself. At times it can be heard to the left of the great vessels at the base, or, again, in the mid-sternal region between the fourth ribs, or in the aortic area, or beyond the sternum on the right side in the nejgh. bourhood of the right nipple. These situations represent the positions in which the murmur is andible in different cases, for in the individual it seldom varies, bnt confines itself to a particular part of the heart area under certain circumstances. I have ventured to account for the cardio-muscalar or neurotyptic murmur by the shock or muscular vibration theory. To explain the cardio-respiratory bruit, on the other hand, it seems necessary to suppose a sudden reduction in the volume of the heart as the result of rapid ventricular contraction, the consequence of which is that the air is drawn in from the tubes, and thus the blowing or wbiffing sound is produced. The following case I adduce as perhaps the most striking example of the cardio-respiratory murmar with which I have met.

CASE 5.-A man aged fifty-two was sent to me by a medical friend as a case of aortic disease. The patient stated that he had been in good health prior to an attack of pneumonia of the right lung some seven years before. This illness left him in a weak condition for a considerable period. Two years later he noticed beating in the epigastrium, and still later palpitation, with frequent intermissions. Then he became very nervous, and on one occasion be fell in the street during an attack of palpitation. After this his heart distarbance grew worse, and pains in the left side of the chest, shoulder, and down the left arm (psendo-angina) were added to his other symptoms. At the time he came under observation the pain was a decided feature, and recurred two or three times a day, usually as the result of exertion. He was a tall, thin man, with a nervous, excitable temperament. The heart was rapid (generally about 90 ) and the impulse was diffased and heaving. The apex, as far as it was possible to localise it, was below the fifth rib, an inch and a half below and half an inch to inside of the left nipole. On auscultan tion when the patient was standing a loud systolic blowing or whiffing brait was audible to the right of the sternum in the third, fourth, and fifth interspaces. The point of maximum intensity was in the fourth interspace, immediately below the right nipple; but the murmur was distinctly to be heard over an area which conld be covered by a small hand, reaching from the right border of the sternum beyond and below the nipple. It was not andible at any other part of the heart region. It was londest during the latter part of inspiration and grew weaker as the air left the chest, but was quite inandible when the patient held his breath at the end of a long inspiration. The marmur at once diminished in intensity phen the recamhert posture was assumed; thus, when lying on the back ic was only audible towards the end of inspiration, whilst it disappeared entirely when on the right, or left side. This murmar was quite distinct during the whole of the respiratory cycle when the patient was sitting, but it was noticed that after a prolonged rest in this position it became rapidly less and less distinct, until finally it vanished altogether. The brachial artery at the elbow was prominent and tortnous (atheromatous). There was marked pulsation of the abdominal aorta. To sum up the case briefly. A man over fifty was thrown out of a good situation on account of palpitation, with pain and discomfort in connezion with his heart, and on auscultation a loud systolic murmar was andible to the right of the sternum in the third, fourth, and fifth interspaces. The murmar simulated imperfectly the nurmar of obstructive aortic disease. It was, however, audible ontside the aortic area; it was not cond ucted over the mat ubriam sterni, and it became inaudible when the patient held his breath and when he lay on eicher side. It was, therefore, not an organic murmur. Its distribation, its soft, whiffing character, its crescendency during inspiration, and its total disappearance on altering the posture of the body, even under excitement, distinguished it from the rourmurs to which reference has already been made.

In the following case the mnrmur possessed similar properties, but occupied a different position on the chest wall

CASE 6.-A young man aged thirty consulted me for sexaal and other nervous disturbances. There was a sharp, somewhat violent heart impulse (apez), which seemed a little below and to the left of the normal situation. A lond, soft, systolic murmur was audible in the sixth interspace below the extreme apex beat. It was londest towards the end of inspiration and faint during expiration, whilst it disappeared when the patient held his breath at the end of a forced inspiration and when he lay down.

In another case, one of old-standing organic heart disease, in which pronounced double aortic and systolic mitral bruits were audible, and the heart was markedly hypertrophied, a similar soft, whiffing, systolic murmur could be heard quite independent of the organic marmurs, in the seventh interspace below and to the outside of the apex line. This murmur was only present when the patient lay on his left side at a certain very constant angle. On failing to attain this point, or on over-reaching it a little, the murmur could not be heard.

I now come to an interesting case, which I must dfscribe rather more at length, as it possesses considerable interest from a life assurarce point of view.

CASE 7.-A man aged thirty-two, following a sedentary occupation, came to me about his heart because he had been rejected on two medical examinations for life assurance. He had always been nervous. and of late his nervous symptoms had increased. For two and a balf years he suffered occasionally from palpitation and violent action of the heart, but he had never known what it was to be breatbless on exertion. He was able to take long walks and climb hills, and he frequently rode a bicycle. His father died suddenly some siz years previously from thorac'c aneurysm, and to the shock received at the time he ascribed a good deal of his nervousness, and especially his heart symptoms. He was examined in 1886 for life assurance (two years before his father's death), when his proposal was accepted. In January, 1893, he desired to add to the policy, bnt was rejected on account of his heart. In March, 1894, be made a further application, when another (independent) adverse report was made. He was a tall, thin, fatr man, highly intelligent, but very nervous. He pever suffered from rheumatism. The heart was rapid (110) and jerky in action. The apex beat was beneath the fifth rib, about half an inch to the inner side of the nipple line. Examined standing, a lond murmur was andiole at and a little to the left of the arvex. It was systoli 
in time and seemed to be formed of two braits combined. It commenced as a rough bnzzing sound and terminated in a soft whiff or blow, and could be traced up to the fourth rib beside the sternum, where, however, it became very feeble. There was also a lond blowing systolic murmur in the second interspace to the left of the sternum. During a slowly drawn, exaggerated inspiration the buzzing portion of the apical marmur became feebler, whilst the whiffing or terminal part grew louder. On the other hand, towards the end of expiration the rough part of the murmur increased in intensity, whilst the soft blowing part was reduced to a minimum. After half an hour's rest, when the heart was reduced to 85, the murmur vanished altogether from the neighbourhood of the apex except towards the end of a long inspiration, when a short systolic whiff could alone be detected. The murmur in the pulmonary area continued after all cardiac excitement had abated, and was obriously hæmic.

In this case the three functional murmurs united to produce stethoscopic signs that could with difficulty be distingaished from organic heart disease. The brmic was represented by the brait in the left second interspace, the neuro-typtic by the rough buzzing sound in the apical region, and the cardio-respiratory by the soft whiff which brought the systolic murmur to a termination. Bat the application of what I may call the rest, the positional, and the respiratory tests justified the diagnosis of functional disturbance. Not infrequently the murmur is at a maximum when the breath is held at the end of a deep inspiration, and this should be borne in mind.

CASE 8.-A woman aged twenty-seven, stout and fullblooded, consulted me for headaches and pain in the chest and left side. In searching for a cause of the latter pain I came upon a loud systolic murmur about an inch to the left of the heart apex, which was in its normal position. The murmur was short and blowing; it was best heard in the ninth and tenth interspaces in the posterior axillary line, and was londest during inspiration and at a minimum at the end of expiration. On directing her to draw a long breach and hold it the murmur became markedly intensified. There was no hæmic brait. The cardio-respiratory bruit is not always systolic in time, but may follow the first sound like an echo.

CASE 9.-A man aged sixty-nine, highly nervous but wellpreserved, complained of palpitation, some pain in the left side, and increased frequency of micturition. $\mathrm{He}$ was nervous about himself, and suspected diabetes. He informed me that for thirty years he had been suffering from what medical men called mitral disease, but he had become used to the idea, and was not disposed to take a serious view of his heart condition. The heart was rapid (115 in the minute), with a jerking action. The apex was a little below and to the left of the normal position. Examined standing, a loud murmur was andible at the apex and to the right and left of this point; it was short and whiffing, and synchronous with the first sound, and was londest during inspiration, but became much less distinct when the breath was held. When he lay down the brait to the right of the apex in the fifth interspace was no longer synchronous with the first sound. but followed it, jast coming in before the second sound, which was normal. At the apex and to the lelt this separation from the first sound was not recognised. After resting on the back for a while the heart came down to 84 , and the murmur disappeared.

In some of the cases I have related there was more than a suspicion of cardiac hypertrophy, as evidenced by displaced apex beat. Indeed, it might almost be said to be the rule to meet with the impulse slightly lower and further out than the normal situation in cases in which the neuro-typtic murmur is well marked. In other words, it is not uncommon to meet with hypertrophy, real or apparent. Whilst admitting the possibility of some slight degree of hypertrophy, arising out of chronic palpitation or over-action, I am decidedly of the opinion that the increased area of impulse in these cases cannot be regarded as a sufficient indication of bypertrophy or dilatation; for even in the case of habitually quiet, normal hearts, a little excitement or exertion will at once cause an apparent outward displacement of the apex beat, which in some instances will continue in the new position for a while after the pulse has fallen to its normal rate. This point requires further investigation, for it is obviously of importance to determine the size of the heart, a task of considerable difficulty in cases of nervous palpitation. In very few instances was I able to satisfy myself that the area of percussion dulness was at all increased, and in none did I meet with increase in the area of deep dulness. It will possibly be thought that the explanation given above of the so-called shock and cardio-respiratory murmurs are inadequate, and so they may be ; but I am not so much concerned jast now with the theory of their production as I am to bring under the notice of the profession the fast that functional heart murmurs very often simulate organic disease. The accompanying table shows the chief clinical features of the various murmurs :-

Table showing the Characteristics of Different Murmurs.

\begin{tabular}{|c|c|c|c|c|}
\hline - & $\begin{array}{l}\text { Organic } \\
\text { mitral. }\end{array}$ & Hæmic. & $\begin{array}{l}\text { Neuro- } \\
\text { typtic. }\end{array}$ & $\begin{array}{l}\text { Cardio-respi- } \\
\text { ratory. }\end{array}$ \\
\hline $\begin{array}{c}\text { Physical } \\
\text { character. }\end{array}$ & $\begin{array}{l}\text { Varied, soft, } \\
\text { or rough. }\end{array}$ & $\begin{array}{l}\text { Usually soft; } \\
\text { may b e } \\
\text { rough. }\end{array}$ & $\begin{array}{l}\mathrm{R} \text { o u } \mathrm{g} \text { h, } \\
\text { scratching, } \\
\text { whizzing. }\end{array}$ & Sort, whiffing. \\
\hline $\begin{array}{c}\text { Position of } \\
\text { maximum. }\end{array}$ & $\begin{array}{l}\text { A pex and } \\
\text { conducted } \\
\text { tow ard } \\
\text { left. }\end{array}$ & $\begin{array}{l}\text { P u lmonary } \\
\text { area rarely } \\
\text { be y o nd } \\
\text { apex. }\end{array}$ & $\begin{array}{l}\text { Little above } \\
\text { and toright } \\
\text { of a pex. } \\
\text { Loudest in } \\
\text { fourth in- } \\
\text { terspace } \\
\text { close to } \\
\text { sternum. }\end{array}$ & $\begin{array}{l}\text { Varied in posi- } \\
\text { tion; often not } \\
\text { referable to } \\
\text { any particular } \\
\text { area. }\end{array}$ \\
\hline $\begin{array}{l}\text { Posture } \\
\text { test. }\end{array}$ & $\begin{array}{l}\text { But slightly } \\
\text { in fuenced } \\
\text { by change } \\
\text { of position. } \\
\text { Lo ud est } \\
\text { when lying } \\
\text { on left side. }\end{array}$ & $\begin{array}{l}\mathrm{L} \text { o u d e s t } \\
\text { when lying } \\
\text { on the back. } \\
\text { F a intest } \\
\text { when stand- } \\
\text { ing. }\end{array}$ & $\begin{array}{l}\text { L o u dest } \\
\text { when stand- } \\
\text { ing; often } \\
\text { disappears } \\
\text { when lying } \\
\text { on either } \\
\text { side. }\end{array}$ & Do. Do. \\
\hline $\begin{array}{l}\text { Respira- } \\
\text { tory test. }\end{array}$ & $\begin{array}{l}\text { Loudest at } \\
\text { end of expi- } \\
\text { ration, but } \\
\text { not much } \\
\text { in fuenced } \\
\text { by respira- } \\
\text { tion. }\end{array}$ & $\begin{array}{l}\text { Loudest at } \\
\text { end of ex- } \\
\text { pir a ti ion, } \\
\text { often in- } \\
\text { audible at } \\
\text { end of deep } \\
\text { inspiration. }\end{array}$ & Do. do. & $\begin{array}{l}\text { Loudest to- } \\
\text { wards end of } \\
\text { ins siration, } \\
\text { faintestatend } \\
\text { of expiration. } \\
\text { On holding a } \\
\text { long breath } \\
\text { will often dis- } \\
\text { appear, but } \\
\text { may be inten- } \\
\text { sified. }\end{array}$ \\
\hline Rest test. & $\begin{array}{l}\text { Not much } \\
\text { affected by } \\
\text { exertion. } \\
\text { Well-mark- } \\
\text { ed af ter } \\
\text { prolonged } \\
\text { rest. }\end{array}$ & $\underset{\text { after rest. }}{\mathrm{L} \text { o } \mathrm{d} \quad \mathrm{d} \in \mathrm{s} t}$ & $\begin{array}{c}\text { L o u d e s } \mathrm{t} \\
\text { after exer- } \\
\text { tion or any } \\
\text { e x e i t e- } \\
\text { ment. In- } \\
\text { a u d i ble } \\
\text { after pro- } \\
\text { longed rest }\end{array}$ & $\begin{array}{l}\text { Loudest dur- } \\
\text { ing excite- } \\
\text { ment, may be } \\
\text { in a d ible } \\
\text { after rest. }\end{array}$ \\
\hline
\end{tabular}

Saville-place, Newcastle-on-Tyne.

ON THE

PRESENCE OF TYPHOID BACILLI IN THE URINE OF PATIENTS SUFFERING FROM TYPHOID FEVER.

BY A. E. WRIGHT, M D. DUB.,

PROFESSOR OF PATHOLOGY, ARMY MEDICAL SCHOOL, NETLEY; AND

SURGEON-MAJOR D. SEMPLE M.D.U. IREL ASSISTANT PROFESSOR OF PATHOLOGY, ARMY MEDICAL SCHOOL, NETLEY.

THe fact that typhoid bacilli are to be found in the urine of patients suffering from typhoid ferer is not a new fact. It is, however, a very important fact, and for these reasons. First, if it is true that the typhoid bacilli are present in the urine of patients suffering from typhoid fever, and if, as we shall see, typhoid bacilli are generally absent from the fæces, it will be evident that it is the urine, and not the fæces, of patients suffering from typhoid fever which is responsible for the spread of typhoid infection. Secondly, if typhoid bacilli are constantly present in the urine of typhoid patients, it may be possible to diagnose the presence or absence of typhoid fever by undertaking a bacteriological examination of the urine. Thirdly, if it is true that typhoid bacilli are constantly present in the urine in cases of typhoid fever while they are generally absent from the fæces, it will be evident that the conception of typhoid fever upon which the ordinary clinician proceeds is an entirely erroneous one. It will be convenient to proceed immediately with the discussion of this question. The theory of typhoid fever, which is currently held, and currently acted upon, is the theory that typhoid 